DOI: 10.38136/jgon.673678

\title{
Yaşamın Üçüncü Gününde Preterm Bebeklerde Hemodinamik Olarak Anlamlı Patent Duktus Arteriozusun Tanısında Klinik Bulguların Önemi
}

\section{Diagnostic Value of Clinical Criteria in the Diagnosis of Hemodynamically Significant Patent Ductus Arteriosus in the Preterm Infants on Their Third Day of Life}

\author{
Özkan ILHAN \\ Sinem AKBAY \\ Senem ALKAN ÖZDEMIR ${ }^{2}$ \\ Ali Rahmi BAKILER \\ Berat KANAR \\ Seyma MEMUR \\ Meltem BOR ${ }^{4}$ \\ Esra ARUN ÖZER
}

(1) orcid id:0000-0002-6124-9796
(1) orcid id:0000-0003-0474-7120
(1) orcid id:0000-0003-1266-320X
(1) orcid id:0000-0001-8234-3071
(1) orcid id:0000-0001-7886-8932
(1) orcid id:0000-0001-6099-7496
(1) orcid id:0000-0002-4171-2149
(1) orcid id:0000-0003-2634-7136
${ }^{1}$ MD, Neonatologist, Department of Neonatology, Tepecik Training and Research Hospital, Izmir, Turkey.
${ }^{2}$ MD, Neonatologist, Department of Neonatology, Dr. Behcet Uz Children's Hospital, Izmir, Turkey.
${ }^{3}$ MD, Professor in Pediatrics and Consultant Pediatric Cardiologist, Department of Pediatric Cardiology, Tepecik Training and Research Hospital, Izmir, Turkey.
${ }^{4}$ MD, Neonatologist, Harran University School of Medicine, Department of Neonatology, Sanliurfa, Turkey.

\section{öz}

Amaç: Bu çalışmanın amacı preterm bebeklerde yaşamın üçüncü gününde hemodinamik olarak anlamlı patent duktus arteriozusun (PDA) tanısında ekokardiyografik bulgularla klinik bulguları karşılaştırmaktır.

Gereç ve Yöntemler: Bu retrospektif çalışmaya 31. gestasyonel hafta ve 1250 gramın altında doğan, yaşamın üçüncü gününde ekokardiyograf yapılan 47 preterm bebek alındı. Klinik bulguların hemodinamik olarak anlamlı PDA'yı öngörüp öngörememesi primer sonuç olarak belirlendi.

Bulgular: Çalışmaya alınan 47 preterm bebeğin ekokardiyografik olarak 29'unda hemodinamik olarak anlamlı PDA (hemodinamik olarak anlamlı PDA grubu) tespit edilirken, 18'inde PDA tespit edilmedi (kontrol grubu). Takipne ve artmış oksijen intiyacı oranı hemodinamik olarak anlamlı PDA grubunda kontrol grubuna göre anlamlı olarak daha yüksekti (sırasıyla, $p$ $=0.01$ ve $p=0.004$ ). Taşikardi, hipotansiyon ve metabolik asidoz oranı hemodinamik olarak anlamlı PDA grubunda anlamlı olarak daha yüksekti (sırasıyla, $p=0.03, p=0.004$ ve $p=0.005$ ). Üfürüm, hiperdinamik prekordiyum ve genişlemiş nabız basıncı açısından gruplar arasında anlamlı fark saptanmadı. Takipne, artmıs oksijen intiyacı, taşikardi ve hipotansiyon oranı hemodinamik olarak anlamlı PDA grubunda anlamlı olarak daha yüksek olsa da, lojistik regresyon analizinde sadece metabolik asidozun hemodinamik olarak anlamlı PDA'yı öngörebileceği gösterildi [OR:7.10 ( $p$ $=0.02, \% 95 \mathrm{Cl}: 1.34-37.53)]$

Sonuç: Metabolik asidoz, preterm bebeklerde yaşamın üçüncü gününde hemodinamik olarak anlamlı PDA'yı öngörmede en güvenilir klinik bulgudur.

Anahtar sözcükler: Klinik bulgular, ekokardiyografi, yenidoğan, patent duktus arteriozus, preterm.

\section{ABSTRACT}

Aim: The purpose of this study is to compare the clinical criteria of preterm infants on their third day of life with their echocardiographic findings for the correct diagnosis of hemodynamically significant patent ductus arteriosus (hsPDA).

Material And Methods:The infants with a gestational age of $<31$ weeks and with a birth weight of $<1250 \mathrm{~g}$ who underwent echocardiography on their third day of life were included in this retrospective study. The primary motive of this study is to identify whether clinical findings are feasible in the prediction of hsPDA.

Results: Of the 47 preterm infants, 29 had hsPDA (the hsPDA group) and 18 did not had patent ductus arteriosus (the control group). This observation was made by an echocardiographic examination. The rate of tachypnea and increased oxygen requirement were statistically significantly higher in the hsPDA group than in the control group $(p=0.01$ and $p=0.004$, respectively). The incidence of tachycardia and hypotension was statistically significantly higher in the hsPDA group than in the control group $(p=0.03$ and $p=0.004$, respectively). The rate of metabolic acidosis was significantly higher in the hsPDA group than in the control group $(p=0.005)$. There were no significant differences in murmur, hyperdynamic precordium, and widened pulse pressure between the groups. Although the rates of tachypnea, increased oxygen requirement, tachycardia, hypotension, and metabolic acidosis were statistically significantly higher in the hsPDA group, the logistic regression demonstrated that the metabolic acidosis was the only significant predictor of hsPDA [OR:7.10 ( $p=0.02,95 \% \mathrm{Cl}: 1.34-37.53)]$.

Conclusion: Metabolic acidosis is the most reliable clinical finding for the prediction of hsPDA in the preterm infants on the third day of life.

Keywords: Clinical criteria, echocardiography, newborn, patent ductus arteriosus, preterm.

\section{INTRODUCTION}

The incidence of patent ductus arteriosus (PDA) is around $33 \%$ in very low-birth-weight infants; however, it may be as high as $65 \%$ in the extremely low-birth-weight (ELBW) infants $(1,2)$. The pathophysiological characteristics of PDA depend on the left-to-right shunting as wells as on the effects of shunting on the hemodynamic stability (3). Ductus arteriosus functionally closes 72 hours after birth in the term babies (4). 
However, the closure of ductus arteriosus may be delayed in the preterm babies due to respiratory distress syndrome, infections, fluid management, hypoxia, acidosis, a local release of systemic prostaglandins, and systemic hypotension $(3,5)$. If the ductus remains open 72 hours after birth, the leftto-right blood shunting occurs from the aorta to the pulmonary arteries in the preterm babies through PDA. Pulmonary vascular resistance decreases in the following days after birth with an increase in the blood shunting from the aorta to the pulmonary circulation. This leads to pulmonary congestion, pulmonary edema, and respiratory failure. The perfusion of vital organs, such as kidneys, bowel, and brain, is compromised due to decreasing blood flow in the systemic circulation; hence, the body attempts to compensate for compromised perfusion by increasing the cardiac output. The persistence of this condition may lead to various side effects such as prolongation in the mechanical ventilation time, pulmonary hemorrhage, bronchopulmonary dysplasia, necrotizing enterocolitis (NEC), renal injury, intraventricular hemorrhage (IVH), periventricular leukomalacia (PVL), and, even, death (4).

The characteristics of hemodynamically significant PDA (hSPDA) are: ductus diameter that is greater than $1.5 \mathrm{~mm}$ and observed on Doppler echocardiography;left atrium-to-aortic-root ratio $\geq 1.4$; the observation of holodiastolic inverse flow in the descending aorta; and the enlargement of the left ventricle $(6,7)$.

The clinical presentation of a large PDA with a left-to-right shunt typically occurs after the third day of birth during an acute recovery period of hyaline membrane disease (8). hsPDA may present with murmur, bounding pulse, widened pulse pressure, hyperactive precordium, tachycardia, an increasing demand for respiratory support or oxygen requirement, and hypotension (8, 9).

The purpose of this study is to compare the clinical criteria of preterm infants on their third day of life with their echocardiographic findings for the correct diagnosis of hemodynamically significant patent ductus arteriosus (hsPDA).

\section{PATIENTS AND METHODS}

We conducted this retrospective and comparative study in the Neonatology Department of Tepecik Training and Research Hospital, Izmir, Turkey between January 2014 and December 2014. The inclusion criteria of this study were the preterm infants born with a gestational age (GA) below 31 weeks and the birth weight below $1250 \mathrm{~g}$ who underwent an echocardiographic examination on their third day of life, whereas the exclusion criteria of this study were the preterm infants with chromosomal defects, asphyxia, congenital heart disease, congenital metabolic disorder, and major congenital anomalies. The local ethics committee granted approval for this study. The parents of all the patients provided informed consent for participation in this study.

Demographic characteristics, such as GA at the time of delivery, birth weight, sex, mode of delivery, multiple pregnancies, sepsis, antenatal steroid administration, mechanical ventilation after birth, neonatal outcomes, and death, were retrieved from the medical records. Clinical findings, such as respiratory rate, oxygen requirement, apnea, heart rate, blood pressure, widened pulse pressure, hyperdynamic precordium (visible ictus), murmur, and blood gas, were collected from the files of the enrolled patients. When the $\mathrm{pH}$ value was less than 7.25 and/or the base excess value was less than $-7 \mathrm{mmol} / \mathrm{L}$ during the measurements of blood gas, then the condition of metabolic acidosis was considered. Furthermore, the following complications were recorded: IVH grading was defined according to the research of Papil et al. (10); Stage II and III NEC was defined according to the Bell staging criteria (11), chronic lung disease (CLD) was defined by the oxygen requirement at the 36th week of corrected $\mathrm{GA}(12)$, retinopathy of prematurity (ROP) was defined according to the international classification (13), and death prior to discharge.

Irrespective of their clinical symptoms, all preterm infants underwent an echocardiographic examination on their third day of life (equal to 72 hours) by some selected pediatric cardiologists. The criteria of occurrence of hsPDA were as follows: the ductal diameter being greater than $2 \mathrm{~mm}$; the left atrium-to-aorta ratio being greater than 1.4; the presence of left-to-right shunting of blood; the reversal of end-diastolic blood flow in the aorta; and poor cardiac functions (defined as left ventricular fractional shortening by less than $40 \%$ and the left ventricular output [LVO] less than $350 \mathrm{ml} / \mathrm{kg} / \mathrm{min}$ ). The infants were classified into the two groups: neonates who had hsPDA (the hsPDA group) and neonates who did not have PDA (the control group). The infants with PDA who did not show the criteria of hsPDA in the echocardiogram findings were not included in the study. The first-choice drug for hsPDA treatment was ibuprofen; however, if, in case, ibuprofen was contraindicated, then the intravenous administration of paracetamol was started. There was no surgically closed duct.

The primary motive of this study is to identify whether the clinical findings, such as tachypnea (>60 breaths/min), increased oxygen requirement (the need to maintain the oxygen saturation between $90 \%$ and $95 \%$ with $\mathrm{FiO} 2$ $\geq 0.40$ ), apnea, the presence of persistent tachycardia ( $>180$ beats $/ \mathrm{min}$ ), hypotension, widened pulse pressure (if the difference between the systolic and diastolic blood pressure is greater than $25 \mathrm{mmHg}$ or exceeds half of the value of the systolic blood pressure), hyperdynamic precordium, murmur, and metabolic acidosis, are feasible in the prediction of hsPDA within 72 hours of birth. The secondary outcomes were death prior to discharge and major neonatal morbidities such as IVH, PVL, NEC, ROP, and CLD.

\section{STATISTICS}

The Statistical Package for the Social Sciences (SPSS) version 18.0 software (SPSS Inc., Chicago, IL, USA) analyzed the statistical data of this study. The continuous variables were compared by using the Student's t test or MannWhitney Utest, whereas the categorical variables were analyzed by using the chi-square test or Fisher's exact test. Logistic models were summarized in the $p$ values and adjusted odds ratios (OR) with estimated 95\% confidence intervals $(\mathrm{Cl})$. For the estimation of non-parametric values, we used the Kruskal-Wallis test. A p value of less than 0.05 was considered statistically significant for this study.

\section{RESULTS}

A total of 72 preterm infants with a GA of $<31$ weeks and with a birth weight of $<1250 \mathrm{~g}$ were admitted to the neonatal intensive care unit during the study period. 4 infants who died within 3 days of life were excluded. 68 infants had echocardiography on day 3 of life. Among them, 21 were excluded due to perinatal asphyxia, major congenital malformations, small PDA and refusing participation. Finally, 47 patients were included in the study. Of these 47 patients, 29 (61.7\%) had hsPDA (hsPDA group) and 18 (38.3\%) had no PDA (control group) (Figure 1).

Figure 1. Consort flow diagram of the study. hsPDA, hemodynamically significant patent ductus arteriosus; NICU, neonatal intensive care unit.

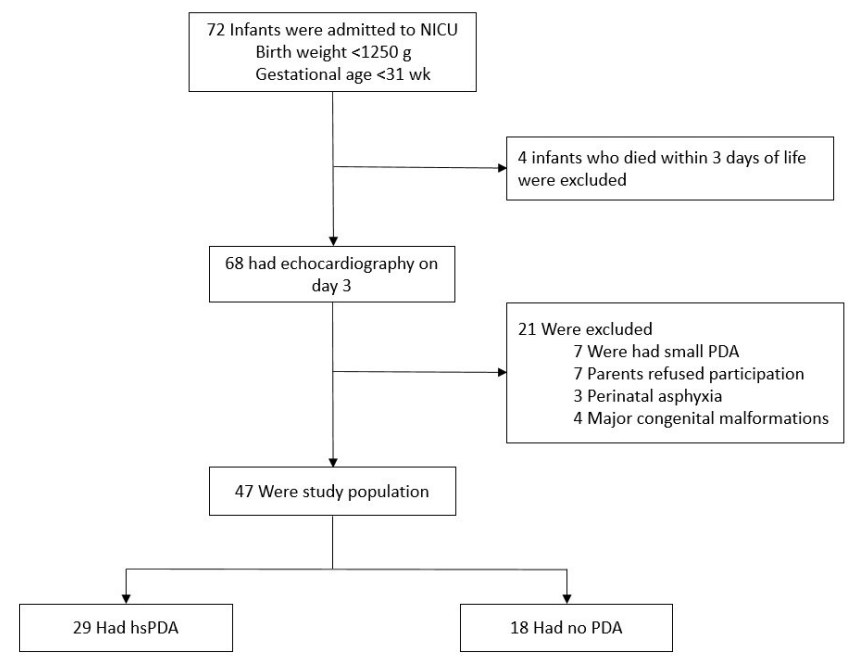

The two groups did not share a considerable difference in the demographic characteristics of the infants; however, the rate of surfactant administration was significantly higher in the hsPDA group than in the control group $(p=$ 0.04) (Table 1).

Table 1. Demographic characteristics of the patients.

\begin{tabular}{|c|c|c|c|}
\hline & $\begin{array}{c}\text { hsPDA group } \\
(n=29)\end{array}$ & $\begin{array}{c}\text { Control group } \\
(n=18)\end{array}$ & $\mathbf{P}$ \\
\hline Gestational age (weeks) $)^{\#}$ & $28(22-30)$ & $27.5(23-30)$ & 0.57 \\
\hline Birth weight (g) $)^{\#}$ & $960(530-1240)$ & $990(500-1230)$ & 0.87 \\
\hline Male gender, n (\%) & $19(65.5)$ & $10(55.6)$ & 0.49 \\
\hline Type of delivery (section), n (\%) & $23(79.3)$ & $15(83.3)$ & 0.32 \\
\hline Apgar score at 5 min $^{\#}$ & $8(5-9)$ & $8(5-9)$ & 0.25 \\
\hline Multiple gestation, n (\%) & $4(13.8)$ & $1(5.6)$ & 0.37 \\
\hline Complete antenatal steroid, n (\%) & $13(44.8)$ & $8(44.4)$ & 0.98 \\
\hline
\end{tabular}




\begin{tabular}{|c|c|c|c|}
\hline Surfactant administration, $\mathrm{n}(\%)$ & $25(86.2)$ & $11(61.1)$ & 0.04 \\
\hline Maternal preeclampsia, n (\%) & $11(37.9)$ & $6(33.3)$ & 0.75 \\
\hline PPROM > 18 h, n (\%) & $3(10.3)$ & $3(16.7)$ & 0.66 \\
\hline \multicolumn{4}{|l|}{ Ventilation support on day 3 of life } \\
\hline $\begin{array}{l}\text { Non-invasive ventilation, } n \\
(\%)\end{array}$ & $16(55.2)$ & $13(72.2)$ & 0.24 \\
\hline $\begin{array}{l}\text { Mechanical ventilation, } n \\
(\%)\end{array}$ & $13(44.8)$ & $5(27.8)$ & 0.24 \\
\hline Length of hospital stay (day) & $51(5-220)$ & $61.5(6-150)$ & 0.79 \\
\hline
\end{tabular}

Values are expressed as \#median (interquartile range) or number (\%). hsPDA, hemodynamically significant patent ductus arteriosus; PPROM, premature prolonged rupture of membranes.

Table 2. Comparison of clinical criteria of the patients in the study group.

\begin{tabular}{|c|c|c|c|}
\hline & $\begin{array}{l}\text { hsPDA group } \\
(\mathrm{n}=\mathbf{2 9})\end{array}$ & $\begin{array}{l}\text { Control group } \\
(n=18)\end{array}$ & $\mathbf{P}$ \\
\hline \multicolumn{4}{|l|}{ Respiratory status } \\
\hline Tachypnea, n (\%) & $15(51.7)$ & $3(16.7)$ & 0.01 \\
\hline IOR, n (\%) & $19(65.5)$ & $4(22.2)$ & 0.004 \\
\hline Apnea, n (\%) & $12(41.4)$ & $8(44.4)$ & 0.83 \\
\hline \multicolumn{4}{|l|}{ Hemodynamic instability } \\
\hline Tachycardia, n (\%) & $9(31.0)$ & $1(5.6)$ & 0.03 \\
\hline Hypotension, n (\%) & $5(17.2)$ & $1(5.6)$ & 0.004 \\
\hline Metabolic acidosis, n (\%) & $23(79.3)$ & $7(38.9)$ & 0.005 \\
\hline Widened pulse pressure, n (\%) & $3(10.3)$ & $1(5.6)$ & 0.56 \\
\hline $\begin{array}{l}\text { Hyperdynamic precordium, n } \\
(\%)\end{array}$ & $1(3.4)$ & 0 & 0.42 \\
\hline Murmur, n (\%) & $4(13.8)$ & 0 & 0.09 \\
\hline
\end{tabular}

Values are expressed as number (\%).

hsPDA, hemodynamically significant patent ductus arteriosus;IOR, increased oxygen requirement.

Table 3. Sensitivity, specificity, positive predictive value and negative predictive value of clinical findings.

\begin{tabular}{lcccc}
\hline Clinical findings & Sensitivity (\%) & Specificity (\%) & PPV (\%) & NPV (\%) \\
\hline Tachypnea & 51.7 & 83.3 & 83.3 & 51.7 \\
IOR & 65.5 & 77.7 & 82.6 & 58.3 \\
Tachycardia & 31.0 & 94.4 & 90.0 & 54.0 \\
Hypotension & 17.2 & 94.4 & 83.3 & 41.4 \\
Acidosis & 79.3 & 61.1 & 76.6 & 64.7 \\
\hline
\end{tabular}

IOR, increased oxygen requirement; PPV, positive predictive value; NPV, negative predictive value.

Table 4. Morbidities and mortality of the patients in the study group.

\begin{tabular}{lccc}
\hline & $\begin{array}{c}\text { hsPDA group } \\
(\mathbf{n = 2 9})\end{array}$ & $\begin{array}{c}\text { Control group } \\
(\mathbf{n}=\mathbf{1 8})\end{array}$ & P \\
\hline IVH, n (\%) & $15(51.7)$ & $4(22.2)$ & 0.04 \\
PVL, n (\%) & $4(13.8)$ & 0 & 0.28 \\
NEC, n (\%) & $8(27.6)$ & $3(16.7)$ & 0.39 \\
ROP, n (\%) & $5(17.2)$ & $5(27.8)$ & 0.39 \\
CLD & $18(62.1)$ & $8(44.4)$ & 0.23 \\
Death,, $\mathbf{n}(\%)$ & $11(37.9)$ & $4(22.2)$ & 0.26 \\
\hline
\end{tabular}

Values are expressed as number (\%).

hsPDA, hemodynamically significant patent ductus arteriosus;IVH, intraventricular hemorrhage; PVL, periventricular leukomalacia; NEC, necrotizing enterocolitis; ROP, retinopathy of prematurity; CLD, chronic lung disease.

In addition, the assessment of the aforementioned significantly different parameters on the logistic regression demonstrated that metabolic acidosis is the only significant predictor of hsPDA [OR: $7.10(p=0.02,95 \% \mathrm{Cl}: 1.34-37.53)$ ]. Although the rates of tachypnea ( $p=0.49$, OR: $1.89,95 \% \mathrm{Cl}: 0.30-11.81)$, increased oxygen requirement ( $p=0.51, \mathrm{OR}: 1.80,95 \% \mathrm{Cl}: 0.31-10.43)$, tachycardia ( $p=0.28$, OR: $8.74,95 \% \mathrm{Cl}: 0.17-446.20)$, hypotension $(p=0.91$, OR: $1.22,95 \% \mathrm{Cl}: 0.02-61.68)$, and surfactant administration ( $p=0.20$, OR: $3.25,95 \% \mathrm{Cl}: 0.52-20.37$ ) were statistically significantly higher in the hsPDA group than in the control group, the difference between the ratios was not statistically significant.

\section{DISCUSSION}

In this trial we found that the incidence rates of tachypnea, increased oxygen requirement, tachycardia, hypotension, and metabolic acidosis were significantly higher in the hsPDA group than in the control group without PDA. The rates of murmur, hyperdynamic precordium, and widened pulse pressure were similar between the hsPDA and control groups without PDA. Also our findings shows that for hsPDA, metabolic acidosis had the highest sensitivity, whereas tachycardia had the highest specificity and a positive predictive value. The logistic regression revealed that metabolic acidosis was the only significant predictor factor of hsPDA.

Echocardiography has been the gold standard method for the diagnosis of hsPDA because clinical findings are not reliable in the early diagnosis of hsPDA (14). Some researchers recommend the routine use of echocardiography at the third day of birth in the ELBW infants, whereas some researchers only suggest the use of echocardiography if the clinical findings are presenting the symptoms of hsPDA (3).

Depending on the GA, respiratory changes associated with PDA can be observed on the first day of birth; however, these changes may also occur several days after birth (15). Pourarian et al. (16) found that oxygen dependence is not a viable indicator in predicting the presence of PDA. McNamara et al. (17) reported that the frequency of apnea, oxygen requirement, and ventilator dependence are observed more often with an increase in the left atrium-to-aortic annulus ratio and transductal diameter during hsPDA. Zonnenberg et al. (9), in their review of 67 studies, suggested the evaluation of the respiratory findings, such as an increase in the need for respiratory support and inability of weaning from the ventilation in the diagnosis of hsPDA. In another trial (18) examined a cohort of preterm infants daily over the first week after birth with independent and blinded clinical and echocardiographic examinations. The presence of signs often correlates with the presence of a PDA, but the symptomatic PDAs did not produce the clinical signs. In this study, although respiratory findings such as tachypnea and increased oxygen requirement were significantly more common in the patients diagnosed with hsPDA on echocardiography at the third day after birth, the logistic regression demonstrated that the difference between the ratios was not statistically significant.

The left-to-right shunt due to PDA decreases both the systemic blood flow and the preterm infants' attempt to increase the low systemic blood flow by increasing the LVO. This is mainly accomplished by an increase in the stroke volume rather than the heart rate. There is a considerable decrease in the blood flow to the major organs despite an increase in the LVO. There is a flow across the ductus all throughout the cardiac cycle, and the direction of this flow depends on the difference between systemic and pulmonary pressures. Usually at the beginning of cardiac systole during which the pressure gradient is the highest, shunting from the systemic circulation to pulmonary circulation occurs along with a phenomenon known as ductal steal during the complete cardiac cycle. The phenomenon of ductal steal results in systemic hypoperfusion despite an increase in the cardiac output. This causes a decreased perfusion and oxygenation in patients with hsPDA (19). Evans et al. (20) reported that both systolic and diastolic blood pressures are lower in early preterm babies with hsPDA at the first week of birth. Han et al. (21) demonstrated that both systolic and diastolic blood pressures are lower in the preterm infants with hsPDA than in the control infants without PDA after 72 hours of birth. These findings were suggested to be clinically useful in the diagnosis of hsPDA in the preterm infants. Furthermore, they recommended the use of echocardiography for an early diagnosis and treatment on the detection of hypotension. Several studies suggested that the presence of tachycardia bears clinical significance for the diagnosis of hsPDA $(3,16$, $22,23)$. Alagarsamy et al. (24) compared the preterm infants with and without PDA within 48-72 hours after birth according to the clinical criteria and echocardiographic findings. In addition, they reported that the preterm infants with PDA had a higher pulse rate and a lower mean blood pressure. Some studies have included metabolic acidosis into the clinical criteria of hsPDA $(23,25)$. McNamara et al. (17) classified hsPDA according to the clinical and echocardiographic findings and they associated moderate hsPDA with mild metabolic acidosis and severe hsPDA with moderate-to-severe metabolic acidosis. In this study, tachycardia, hypotension, and metabolic acidosis were significantly higher in the patients with hsPDA than in the control group; however, the 
logistic regression showed that only metabolic acidosis was the statistically significant predictor of hsPDA. The widened pulse pressure was only found in three patients, and this clinical finding was considered to be of no clinical use in the diagnosis of hsPDA.

Another important point was mostly the infants who were included to the study was administrated surfactant. Previous data regarding the impact of surfactant administration on hsPDA in preterm infants are not clear (26). Studies showed that a fall in pulmonary pressure which was followed by an increase in transductal shunt, with an increase in LVO occurred after surfactant administration $(27,28)$. Conversely, Sehgal et al. (29) found the early surfactant administration was associated with an increase in the ductal size, a predominant left to right transductal flow and a decrease in LVO. This situation was hypothesized due to left to right transatrial flow, because the foramen ovale is in maximum size after birth. In another study, there was no increase in LVO values of postnatal second hour of life after surfactant administration, but LVO was increased at the end of postnatal 24th hour (26). In our study the first echocardiographic examination of infants performed at the end of postnatal 72th hour, this suggests that the increase in LVO observed is due to the increase in afterload, the change in ductal flow and the increase in peripheral vascular resistance due to postnatal left ventricular adaptation.

Clinical findings, such as murmur, increased pulse volume, and hyperactive precordium, have a low reliability in the diagnosis of hsPDA, particularly within the first four days of birth. Murmur can possibly be associated with PDA, but the absence of murmur does not rule out PDA. Murmur is the most reliable clinical finding, whereas the increased pulse volume and hyperactive precordium in the first week of life is not reliable in confirming the diagnosis of PDA (18). Alagarsamy et al. (24) noted that only one infant had a murmur and one infant had hyperdynamic precordium within 48-72 $\mathrm{h}$ of birth in the 12 infants with hsPDA. They revealed a poor association between the presence of PDA, and heart murmur, hyperdynamic chest, and dorsalis pedis pulse. Skelton et al. (18) showed that the accuracy of clinical signs, such as systolic murmur, increased pulse volume, and precordial hyperactivity, in the detection of hsPDA was poor, particularly in the first four days after birth, and sensitivities for all three signs were very low in the first four postnatal days. From the fourth day onward, the clinical signs, particularly murmur, become much more accurate. Davis et al. (25) stated that the pulse quality and heart murmur had the highest mean sensitivities after the third day of life in the preterm infants with hsPDA. Han et al. (21) demonstrated that the widened pulse pressure was not a viable clinical finding in the diagnosis of hSPDA 72 hours after birth. The most essential factor in the production of murmur sound is the less volume flow rather than an increase in the velocity and resultant turbulence of the fluid; therefore, a murmur does not necessarily signify the development of hemodynamic significance. As a result, clinical signs such as murmur, hyperdynamic precordium, and bounding pulse may not be detected in the first three days of birth. Similar to the studies by Skelton et al. (18) and Han et al. (21), this study found heart murmur in 4 out of 29 patients in the hsPDA group and only 1 had hyperactive precordium. Consequently, these clinical findings are not deemed sufficient in the diagnosing hSPDA on the third day after birth.

In conclusion, although tachypnea, increased oxygen requirement, tachycardia, hypotension, and metabolic acidosis are associated with hsPDA, metabolic acidosis is the most reliable clinical finding that is feasible in the prediction of hsPDA in the preterm infants with GA of less than 31 weeks and birth weight of less than $1250 \mathrm{~g}$. The incidences of heart murmur, bounding pulse, and widened pulse pressure are also not sufficient to diagnose hsPDA. The evaluation of clinical findings may be useful in the diagnosis of PDA and making the correct treatment decision in the preterm infants on the third day after birth.

Acknowledgements: None

Conflicts of Interest Statement: None

\section{REFERENCES}

1.Van Overmeire B, Chemtob $S$. The pharmacologic closure of the patent ductus arteriosus. Semin Fetal Neonatal Med 2005;10(2):177-84.

2.Costeloe K, Hennessy E, Gibson AT, Marlow N, Wilkinson AR. The EPICure study: outcomes to discharge from hospital for infants born at the threshold of viability. Pediatrics 2000;106(4):659-71.

3.Chiruvolu A, Punjwani P, Ramaciotti C. Clinical and echocardiographic diagnosis of patent ductus arteriosus in premature neonates. Early Hum Dev 2009;85(3):147-9.

4.Benitz WE, Committee on Fetus and Newborn, American Academy of Pediatrics. Patent ductus arteriosus in preterm infants. Pediatrics 2016;137(1):e20153730.

5.Behrman RE, RM Kliegman, HB Jensen (eds): Nelson Textbook of Pediatrics. 17th edition. Saunders, Philadelphia 2004;579.

6. Hamrick SE, Hansmann G. Patent ductus arteriosus of the preterm infant. Pediatrics 2010;125(5):1020-30.

7.El Hajjar M, Vaksmann G, Razka T, Kongolo G, Storme L. Severity of the ductal shunt: a comparison of different markers. Arch Dis Child Fetal Neonatal Ed 2005;90(5):419-22.

8.Skinner J. Diagnosis of patent ductus arteriosus. Semin Neonatol 2001;6(1):49-61.

9.Zonnenberg I , de Waal K. The definition of a haemodynamic significant duct in randomized controlled trials: a systematic literature review. Acta Paediatr 2012;101(3):247-51.

10.Papile LA, Burstein J, Burstein R, Koffler H. Incidence and evolution of subependymal and intraventricular hemorrhage: a study of infants with birth weights less than 1,500 gm. J Pediatr 1978;92(4):529-34.

11.Bell MJ. Neonatal necrotizing enterocolitis. N Engl J Med 1978;298(5):281-2. 12.Jobe AH, Bancalari E. Bronchopulmonary dysplasia. Am J Respir Crit Care Med 2001;163(7):1723-9.

13.International Committee for the Classification of retinopathy of prematurity. The international classification of retinopathy of prematurity revisited. Arch Ophthalmol 2005;123(7):991-9.

14.Snider AR, Serwer GA, Ritter SB. Echocardiography in pediatric heart disease. Second ed. Mosby Inc 1997;452-8.

15.Clyman RI. The role of patent ductus arteriosus and its treatments in the development of bronchopulmonary dysplasia. Semin perinatol 2013;37(2):102-7.

16.Pourarian S, Sharma D, Farahbakhsh N, Cheriki S, Bijanzadeh F. To evaluate the prevalence of symptomatic and non-symptomatic ductus arteriosus and accuracy of physical signs in diagnosing PDA in preterm infants using blinded comparison of clinical and echocardiographic findings during the first week of life: a prospective observational study from Iran. J Matern Fetal Neonatal Med 2017;30(14):1666-70.

17.McNamara PJ, Sehgal A. Towards rational management of the patent ductus arteriosus: the need for disease staging. Arch Dis Child Fetal Neonatal Ed 2007;92(6):424-7.

18.Skelton R, Evans N, Smythe J. A blinded comparison of clinical and echocardiographic evaluation of the preterm infant for patent ductus arteriosus. $J$ Paediatr Child Health 1994;30(5):406-11.

19.Sasi A, Deorari A. Patent ductus arteriosus in preterm infants. Indian Pediatr 2011;48(4):301-8.

20.Evans N, Moor Craft J. Effect of patency of the ductus arteriosus on blood pressure in very preterm infants. Arch Dis Child 1992;67(10 Spec No):1169-73.

21.Han UJ, Cho HJ, Cho YK, Choi YY, Ma JS. Change in blood pressure and pulse pressure in preterm infants after treatment of patent ductus arteriosus with indomethacin. Korean Circ J 2011;41(4):203-8.

22.Tammela O, Ojala R, livainen T, Lautamatti V, Pokela ML, Janas M, et al. Short versus prolonged indomethacin therapy for patent ductus arteriosus in preterm infants. J Pediatr 1999;134(5):552-7.

23.Engur D, Deveci M, Turkmen MK. Early signs that predict later haemodynamically significant patent ductus arteriosus. Cardiol Young 2016(3);26:439-45.

24.Alagarsamy S, Chhabra M, Gudavalli M, Nadroo AM, Sutija VG, Yugrakh D. Comparison of clinical criteria with echocardiographic findings in diagnosing PDA in preterm infants. J Perinat Med 2005;33(2):161-4

25.Davis P, S Turner-Gomes, K Cunningham, C Way, R Roberts, B Schmid. Precision and accuracy of clinical and radiological signs in premature infants at risk of patent ductus arteriosus. Arch Pediatr Adolesc Med 1995;149(10):113641.

26. Vitali F, Galletti S, Aceti A, Aquilano G, Fabi M, Balducci A, et al. Pilot observational study on haemodynamic changes after surfactant administration in preterm newborns with respiratory distress syndrome. Ital J Pediatr 2014;40(1):26.

27. Hamdan AH, Shaw NJ. Changes in pulmonary artery pressure during the acute phase of respiratory distress syndrome treated with three different types of surfactant. Pediatr Pulmonol 1998;25(3):191-5.

28.Kumar A, Lakkundi A, McNamara PJ, Sehgal A. Surfactant and patent ductus arteriosus. Indian J Pediatr 2010;77(1):51-5.

29.Sehgal A, Mak W, Dunn M, Kelly E, Whyte H, McCrindle B, et al. Haemodynamic changes after delivery room surfactant administration to very low birth weight infants. Arch Dis Child Fetal Neonatal Ed 2010;95(5):F345-51. 